\title{
UNDOING CITIZENSHIP. UNDOCUMENTED QUEER ACTIVISM AND PRACTICES OF RIGHTS
}

\author{
Desfazendo a cidadania. O ativismo de indocumentados queer \\ e a prática de direitos
}

Mara Pieri ${ }^{1}$

\begin{abstract}
Within the emergence of migrant activism, the experience of UndocuQueers developed in San Francisco from 2011 challenges common assumption about practices in migrant movements through the intersections between queer and migrant claims. In order to understand their peculiarities, I will first analyse some of the salient characters of UndocuQueer activism. Then, I will focus on the web-series "Undocumented and awkward", in order to discuss the intersectionalities proposed by the movement. In the third part, I will discuss how the series may be framed as examples of groundbreaking practices of citizenship. I will finally argue that UndocuQueer movement and its cultural production offer a ground-breaking example of political practices of rights and propose a promising perspective for a critical engagement with citizenship issues.
\end{abstract}

Keywords: queer, activism, undocumented activism, migrants.

Resumo. No contexto da emergência do activismo migrante, a experiência do UndocuQueers, nascida em San Francisco em 2011, desafia ideias comuns sobre práticas de movimentos migrantes, através das intersecções entre reivindicações queer e migrantes. Para compreender estas peculiaridades, neste artigo procuro em primeiro lugar analisar algumas das características mais relevantes do activismo UndocuQueer. De seguida, concentrome na série online "Undocumented and awkward" ("Sem documentos e estranho"), de modo a discutir as interseccionalidades propostas pelo movimento. Na terceira parte, proponho-me a analisar a série enquanto exemplo de práticas inovadoras de cidadania. Finalmente, discuto como o movimento UndocuQueer e a sua produção cultural oferece um exemplo original de práticas políticas de direitos e propõnho uma perspectiva promissora para um engajamento crítico com questões de cidadania.

Palavras-chave: queer, activismo, activismo dos sem documentos, migrantes.

$\overline{1 \text { PhD Student, CES }}$ - Centre for Social Studies, University of Coimbra. Coimbra, Portugal. 


\section{Introduction}

In the last decade, immigrant activism emerged as a fundamental form of struggle in the European and North-American political scenario. Significant and successful mobilizations lead by undocumented immigrants revealed the need to rethink contemporary scales of citizenship and practices of human rights. These mobilizations gained important results in pressuring political institution and organizations; they also gave visibility to undocumented subjects as active claimants of citizenship. Despite great differences in local dynamics, a trend that connects different experiences is recognisable.

In the U.S.A., the first demonstrations were held in 2006, when thousands of undocumented immigrants publicly marched to claim their rights to be recognised as citizens: the mobilizations, organized through informal channels and under the claim of "No one is illegal", started from Chicago and soon spread in big and small cities, reaching unexpected participation. Their success led some grassroots organizations, together with undocumented immigrants, to launch "A day without immigrants", a massive strike which was repeated later in several countries across the Global North². Within these mobilizations, LGBT and queer activists held a role of primary importance. After being fundamental subjects in the undocumented youth movement for years, in 2011 young and undocumented queers self-defined as UndocuQueers activists. When Barack Obama proposed the DREAM Act as a legal recognition for young sons and daughters of "illegal" immigrants, local and national networks of organizations and single subjects gathered in order to pressure the discussion of the law. The QUIP (Queer Undocumented Immigrant Projects) was thus created within the United We Dream Network. Once this first collective project was launched, several other activists gathered, in particular in San Francisco Bay, and the term UndocuQueer began to define activists which engaged in intersectional practices of activism based on being undocumented and queer ${ }^{3}$.

UndocuQueer activism poses several challenges to contemporary conceptions of citizenship and practices of human rights. Despite some of its dynamics adhere to the mobilizations cited above, UndocuQueer movements present interesting specificities, particularly in regards to practices of rights. In order to understand them more specifically, after analyzing the salient features in the first part, I will then on one particular project lead by UndocuQueer movement, namely the web-series "Undocumented and awkward", in order to discuss the practices of citizenship and the intersectional connections between different identities proposed. I will then discuss how the episodes of the series

\footnotetext{
MARCINIAK, Katarzyna. Legal/illegal: protesting citizenship in Fortress America.

3 WHITE, Melissa Autumn. Documenting the undocumented: Toward a queer politics of no borders.
} 
may be framed as examples of practices of citizenship, drawing from the concept of "acts of citizenship" ${ }^{4}$. I will finally argue that UndocuQueer movement and its cultural production offer a ground-breaking example of political practices of rights and propose a promising perspective for a critical engagement with citizenship issues.

\section{Unexpected subjects: undocumented queers}

The UndocuQueer movement arose in 2011 in response to the need for queer to create specific narratives on the intersections between being undocumented and being queer ${ }^{5}$. Most of them were already engaged in the undocumented mobilizations of the United We Dream Network, which gathered different local committees and organizations. Since the beginning, the choice was to maintain the self-definition of "undocumented" already deployed by the first activists of the "No one is illegal" movement. The definition of undocumented was conceived in response to the accusation of illegality frequently produced in political and common discourses on irregular immigration: the word "illegal", in fact, resembles an idea of immigrants as criminal and lawbreaker subjects who intentionally bypass rules in order to gain citizenship ${ }^{6}$. "Undocumented", on the contrary, focuses on the specific struggle engaged by activists in the context of the discussion of the DREAM Act, which promised citizenship to 'children of illegal immigration', an estimated number of 12 million people who live in U.S.A. without regular permits. The documents lacked by the "undocumented" are those formally declaring a regular migration or residency status, issued by the American government, which give access to a wide range of services, job placements, grants and everyday facilities, such as the driving license. The DREAM Act is considered controversial both by UndocuQueers and by some fringes of the Undocumented Movement: while proposing "citizenship for all", it indeed reproduces exclusionary dynamics based on ideas of good versus bad immigrants; productive versus useless workers; respectful versus criminal subjects ${ }^{7}$. Also, the Act guarantees full recognition of citizenship to those subjects who accept to play the script of the "good American" in a neoliberal regime: subjects who completed high school and post-secondary education, with no criminal records, who have enrolled in the Army for at least two years, engaged in activities of volunteering within local communities. Moreover, the Act is meant for those who entered the country

\footnotetext{
ISIN, Engin. Theorizing acts of citizenship.

I will refer to "queer" as a comprehensive term for LGBT and non-normative identities, according to the self-identification given by activists of the movement.

6 DE GENOVA, Nicholas. The queer politics of migration: Reflections on 'illegality' and incorrigibility.

WHITE, op. cit.
} 
while still children and thus considered incapable of doing it by personal choice. The challenges posed by the DREAM Act are not unproblematic and open several questions for activists: how to relate a struggle to citizenship without falling into categorization? What are the main lines of struggle that can connect queer and undocumented in a common aim?

To answer these questions it is necessary to go a step back to the controversial relationship between non-status subjects and citizenship. As Hannah Arendt $^{8}$ noted in her analyses of stateless people after World War II, human rights are supposed to protect human beings from deprivation and violence; nonetheless, this protection is deployed through recognition of citizenship. Therefore, the more distant subjects are from citizenship, the weaker the capability (or the will) of institutions to provide them human rights protection: therefore, "ironically, it is exactly the stateless who reveal the crisis of human rights" ${ }^{\prime \prime}$. As long as the rights of people are identified with the rights of citizens, the exclusion from citizenship produces the exclusion from a discourse on rights. In the case of undocumented activism, the challenge is posed by subjects that claim their right to be bearer of rights from an invisible position ${ }^{10}$. They are unexpected subjects because their claims for citizenship arise from abjection, a symbolic territory of total exclusion from a possible discourse on rights. Nonetheless, "abjection is an especially apt interpretive frame through which to appreciate the complexities of the migrant condition, precisely because migrants are always already within the space of the state and can never really be entirely expelled"11. Undocumented activism challenges citizenship as it brings unexpected bodies at the centre of the debate. In this sense, if we consider queer politics as practices of contestation and creation of alternatives to normativization and categorization, the condition of invisibility from which they are founded on appears akin to the one from which undocumented claims spring.

The connection between undocumented and queer claims may highly productive and, indeed, the UndocuQueer movement reveals a groundbreaking potential:

Queer anti-deportation and migrant justice activism holds the promising capacity to explicate connections between the intensifying carceral geographies of global apartheid, the vulnerabilities produced through immigration regimes, and the ongoing criminalization of queer and transness as a legacy of colonial rule ${ }^{12}$.

\footnotetext{
8 ARENDT, Hannah. The Jew as Pariah.

9 KRAUSE, Monika. Undocumented Migrants An Arendtian Perspective, p. 337.

${ }^{10}$ NYERS, Peter. No one is illegal between city and nation.

11 DE GENOVA, op. cit., p. 104.

12 WHITE, op. cit., p. 978.
} 
Moreover, both undocumented and queer politics are placed in an unstable position between a critical stand to neoliberal categorization and a tension toward institutional legitimization: the premises of citizenship are then challenged through an active opposition that creates instead of disrupting what Isin defines as "act of citizenship"13.

The challenge to citizenship activated by UndocuQueers involves a redefinition of borders as well. Most of UndocuQueers are indeed born within the U.S.A. territory: they do not fall into the reified category of mobile humans who cross physical borders: they are "immobile immigrants", which, on the contrary, due to their undocumented status are not able to move freely. Nonetheless, they suffer the effects of the control produced by borders in the symbolic and political space and are constantly challenged by the "the production of difference in space, the production of spatial difference" ${ }^{\prime 14}$. The diffuse power of borders is as invisible and pervasive as the heteronormativity assumptions that rule spaces and relations. In fact, heteronormativity defines citizenship towards a heterosexual script, which allows, for example, the right to acquire a status through a legal marriage through a heterosexual marriage, but not through a lesbian or gay marriage. In everyday life, it exposes queer subjects to danger of homophobia, transphobia and discrimination. The constant threat of deportability ${ }^{15}$ experienced by undocumented subjects is enhanced by the exposition to verbal and physical harassment based on homophobia and transphobia: for the precarious condition of undocumented queers, responding to this kind of violence may mean to be deported. The paradox stressed by Arendt still reveals its strength and appears to be embodied in everyday life conditions that reproduce the heteronormative foundation of rights and the exclusionary mechanisms enacted through citizenship.

The challenge posed on citizenship and heteronormativity is founded on a generational premise that constitutes a peculiarity of the Undocumented movement in general, but particularly of the UndocuQueers. The movement was born thanks to the commitment of young generations, mostly born in the U.S.A. from families with undocumented status, or, in any case, who entered the country when children and grew up as Americans. The DREAM Act is directed explicitly to them, considered the "good citizens of tomorrow": the opportunity it offers is to redeem the mistakes committed by an older generation of fathers and mothers who broke the rules and entered the country illegally. This offer has a highly problematic consequence, as it creates a generational conflict within families and groups of support, often the only sources of support

\footnotetext{
${ }^{13}$ ISIN, op. cit.

${ }^{14}$ DE GENOVA, Nicholas. 'We are of the connections': migration, methodological nationalism, and 'militant research', p. 254.

${ }^{15}$ DE GENOVA, Nicholas. Migrant 'Illegality' and deportability in everyday life.
} 
for undocumented subjects. Guilt and salvation, mistakes and correction are oppositional concepts that entered the debate of UndocuQueer activism: they are all connected to an ultimate ideal of the good and the bad citizen. In his controversial analyses of young Italian generations born after the Fascism, Pier Paolo Pasolini states:

One of the most mysterious issues in ancient Greek theatre is the predestination for offspring to pay for their parents' faults. It does not matter whether the sons are good, innocent, and devout: if their parents sinned, they must be punished. The chorus - a democratic chorus - declares to hold this truth: and it enounces that without introduction nor explanation for it appears to be the most natural truth ${ }^{16}$.

In the picture proposed by the DREAM Act, Undocumented teenagers live in deprivation due to faults committed by their fathers and mothers. This enunciation of guilt comes from a democratic chorus, the American Government, which declares it as universal and natural truth. It is the same democratic chorus that offers the opportunity to exit this vicious circle through a salvation offer: the proposal to be recognized as citizens following the parameters that define the good from the bad. The political exclusion produced by multiple means of categorization (citizenship, heteronormativity) is so pervasive that it enters the intimate space of relation between young and older generation: the will to be citizens does not come without costs ${ }^{17}$.

Visibility, citizenship, heteronormativity, borders and conflicts between generations therefore represent the most salient issues that UndocuQueers face and challenge through activism and everyday life.

\section{2. "Undocumented and Awkward": the real reality of undocumented lives}

"I make art so that I don't feel like the only one going thru this shit. Going at it alone is tough. It's sad. We in it together": with this words Julio Salgado summarizes what is behind his artistic practice ${ }^{18}$. He has been the most prominent voice of UndocuQueer movement since its foundation. Through his works of arts, mainly illustrations and videos, he portrayed and told stories of undocumented young queers like him and gave a significant contribution to

${ }_{16}$ PASOLINI, Pier Paolo. Lettere luterane, p. 5. Original in Italian: "Uno dei temi più misteriosi del teatro tragico greco è la predestinazione dei figli a pagare le colpe dei padri. Non importa se i figli sono buoni, innocenti, pii: se i loro padri hanno peccato, essi devono essere puniti. È il coro - un coro democratico - che si dichiara depositario di tale verità: e la enuncia senza introdurla e senza illustrarla, tanto gli pare naturale". Translated by the author.

${ }^{17}$ SEIF, Hinda. 'Coming out of the shadows' and 'UndocuQueer': undocumented immigrants transforming sexuality discourse and activism.

${ }^{18}$ SALGADO, Julio. I make art so that I don't feel like the only one going thru this shit. Going at it alone is tough. It's sad. We in it together. 
the movement ${ }^{19}$. In 2010, together with other three undocumented activists, he founded "Dreamers Adrift" ${ }^{20}$, an innovative platform that produces cultural and artistic contributions on undocumented queer lives:

It is a creative project ABOUT undocumented youth, BY undocumented youth, and FOR undocumented youth. We are trying to document the undocumented. We're putting our life on display through videos, art, music, spoken word, prose and poetry ${ }^{21}$.

Dreamers Adrift counts on the collaboration of activists and artists that together composed a collective and multifaceted narrative. The project has produced several videos that gained high resonance and is still active although the DREAMers movement has weakened its activities. Here, I will focus on one specific production, namely "Undocumented and Awkward", a web-series of 13 episodes uploaded on YouTube during years 2011-2012. In 2015, the first episode of the second season was launched. The episodes have an average duration of three minutes and are completely self-produced, without editing and soundtrack: they are basically long takes with no extra effects. The actors are activists from the UndocuQueer movement, non-professionals and Julio Salgado is himself always present. Every person involved in the production is undocumented. The situations presented are taken from episodes of daily-life, such as a first day at a University seminar, a random conversation with a stranger on a bench, a date in a café. Most of the stories come from personal experiences of undocumented people and the components of Dreamers Adrift. The aim is to narrate the difficult, often awkward and absurd, implications of being a young undocumented and queer in San Francisco. The overall effect, then, is extremely truthful to reality, an effect which lead to define the series as the "nation's most real reality TV"22. Despite the amateur style, the series results particularly interesting for the way it represents the contradictions, the struggles and the connections between a political discourse on rights, citizenship and exclusion and their translation into everyday practices.

In first place, the situations depicted are completely based on daily life activities led in private and public spaces, such as university, streets, bus stop, and cafés. In the everyday stage subjects embody the constant state of deportability that characterizes undocumented status:

As undocumented immigrants living in this country, there are many instances in our lives which result in awkwardness not experienced by American citizens. Things that millions of others take for granted, such as

\footnotetext{
${ }^{19}$ KING, Nia. Undocumented and awkward: an interview with Julio Salgado.

${ }^{20}$ Cf. < http://dreamersadrift.com/>.

${ }^{21}$ DREAMERS ADRIFT. About us.

${ }^{22}$ BIGGERS, Jeff. Undocumented and Awkward video series: Dreamers Adrift is the nation's most real reality TV show.
} 
driving to the grocery store or the ability to go to a bar to enjoy a nice cold beer after a long hard day at work, can turn into awkward silences at best, or deportation situations at worst" 23 .

Citizenship and discourses on rights are sized down to a small symbolic territory of everyday practice, in which subjects embody their state of abjection and build strategies of resistance or accommodation towards it: it is both an intimate and a political practice, in which the personal is political and the individual is collective ${ }^{24}$. This is particularly evident in Episode $5^{25}$, where an undocumented gay boy meets another boy for a first date in a café. The "regular" boy asks the undocumented how was it possible to park in the area: the undocumented, which has no driving licence due to its status, answer evasively. A second later, when it is time to order a drink, the undocumented is reluctant to order a beer; as the other insist, he is forced to show his non-American identification document and is refused to be served with alcohol. Inevitably, the undocumented boy is driven to come out about his status. In only two minutes, a discourse on citizenship invades the intimate, individual and allegedly joyful space of a first date: the undocumented status is almost impossible to hide and produces consequences on the interaction with others ${ }^{26}$. Exclusion takes place in activities and discourses that regular citizens take for granted, such as the issue of driving licence or the possibility of ordering a beer.

In the series, characters are interchangeable and the activists of "Dreamers adrift" actually play each time different roles: in the episode mentioned above, for example, Julio Salgado plays the character of the gay middle-class guy who talks by stereotypes on undocumented, while in others he plays as himself. This inversion contributes to convey the idea that discriminations and misconceptions towards undocumented and queer people are everywhere and are reproduced by everyone, even close friends. This discourse has many connections to the discourse on internalized homophobia, institutional violence and hates speech about LGBT people ${ }^{27}$.

Therefore, intersections between undocumented and queer identity resound with connections between scales and practices of rights and citizenship: the episodes of "Undocumented and Awkward" bring the multiple nuances of these intersections to a visible and explicit level, as they give a face, a voice, a set to the ways they take shape in everyday life. Short, ironical depictions become paradigmatic of a bigger political struggle: they indeed create a

\footnotetext{
${ }^{23}$ RODRIGUEZ, Favianna. Meet the UndocuArtists: using art and culture for immigrant justice, and much more!

${ }^{24}$ WHITE, Melanie. Can an act of citizenship be creative?

${ }^{25}$ DREAMERS ADRIFT. Undocumented and Awkward: Episode 5.

${ }^{26}$ RIVAS, Jorge. What's it like to be young and undocumented? Awkward, says new video.

${ }^{27}$ BUTLER, Judith. Excitable speech: a politics of the performative.
} 
scene $^{28}$ that represents the milieu in which claims for rights arise. Indeed, the reference to relation between scales of mobilization is constant and not unproblematic. In episode $2.1^{29}$, for example, the setting is a seminar group at University who gathers for the first time. People are invited by the coordinator to present themselves so they can feel in "a safe and comfortable place", but the presentations cause a chain reaction of comments and opinions that, all together, reproduce stereotypes, misconceptions, and subtle discriminatory discourses. The undocumented characters find themselves harmless in trying to present another narrative on their experience and on their parents' choice. The topic of generational conflict is represented as inextricable from class, gender and race issues: intersectional identities do reflect intersectional discriminations. In a totally different setting, during Episode $10^{30}$, a group of DREAMers gathers to discuss the advancement of the struggle for the law. One of them makes a homophobic joke using the word "faggots" as a synonymous for "stupid". When asked not to use it anymore by his gay friend, he justifies himself saying: "I'm not being a hypocrite, we're talking about immigrant rights, we're not talking about homosexuality here!". Within the indifference of all the other people present, the queer boy is left alone in facing a typical homophobic verbal violence. While presenting common forms of homophobia, the episode also critically positions within the DREAM Act movement, stating that no activists are indeed immune from reproducing multiple forms of discrimination.

The episodes thus engage in the difficult process of representing intersectionality without simplifications and do not deny the constant need of discussion needed in order to understand where discriminations arise. Moreover, the narrative is at any moment always also a meta-narrative ${ }^{31}$ : what is represented on the screen is taking place, in the same moment, somewhere in reality; the act of being in front of the camera is also a reprocessing of strategies of resistance outside the space of representations.

\section{Unquiet acts of citizenship}

As parts of a broader project by Dreamers Adrift, "Undocumented and Awkward" represents an interesting product of the UndocuQueer movement and may be understood for its rhetorical means ${ }^{32}$, as a form of artivism ${ }^{33}$ (activism through art) or as a political manifesto ${ }^{34}$. I argue that the series may

\footnotetext{
${ }^{28}$ ISIN, op. cit.

${ }^{29}$ DREAMERS ADRIFT. Undocumented and Awkward 2.0: Episode 1.

${ }^{30}$ DREAMERS ADRIFT. Undocumented and Awkward: Episode 10.

${ }^{31}$ ALEXANDER, Jonathan, RHODES, Jacqueline. Sexual rhetorics: methods, identities, publics.

32 Ibidem.

${ }^{33}$ RODRIGUEZ, op. cit.

${ }^{34}$ SEIF, op. cit.
} 
be also framed following the concept of "acts of citizenship" proposed by Isin, a theoretical contribution which refers to all acts "through which citizens, strangers, outsiders and aliens emerge not as beings already defined but as beings acting and reacting with others ${ }^{\prime 35}$. Acts of citizenship are produced by actors that become active subjects in the same moment of enacting practices of rights which were not predicted before. They thus represent a different object of investigation, which is both entangled with and separated from "the status and habitus of citizenship" ${ }^{\prime 36}$. Isin argues that, in fact, while scholars have devoted great interest to the everyday processes of claiming citizenship within institutional frames (the habitus), we still know little on how unexpected subjects become claimants of rights arising from an invisible status. Acts of citizenship represent a creative rupture from the habitus: "acts rupture or break the given orders, practices, habitus. Creative ruptures and brakestake different forms that are irreducible. [...] What actualizes an act is not determinable in advance" ${ }^{\prime 37}$. Thus, not every act is an act of citizenship and not every act of citizenship is inherently positive or successful: nonetheless, subjects constitute themselves as citizens through an active purpose of disrupting the existing framework and to create a citizenship vocabulary which is a constant work in progress. The foundation of citizenship, in this conception, is moved from law to active practice, since acts of citizenship:

Transform forms (orientation, strategies, technologies) and modes (citizens, strangers, outsiders, aliens) of being political by bringing into being new actors as activist citizens (claimants of rights and responsibilities) through creating new sites and scales of struggle ${ }^{38}$.

The theoretical framework proposed by Isin offers valid insights to interpret some of the most interesting features of "Undocumented and Awkward", both as a cultural product and a political creation of narratives. The series tells stories about practices of human rights which are creative, complex and everyday based: practices that present an innovative narrative about the emergence of activist citizens and the implications of intersectional positioning.

In first place, according to Isin, subjects become citizens through the active creation of scenes: creativity resides in the capability to overturn the "theme of lack"39 connected to the status of undocumented and build active practices of resistance and survival. The characters portrayed in the series, claiming their right to have rights, are not portrayed as victims: on the contrary, they are actively deconstructing stereotypes not only about their

\footnotetext{
35 ISIN, op. cit., p. 39.

36 Ibidem, p. 16.

37 Ibidem, p. 36.

38 Ibidem.

${ }^{39}$ NYERS, op. cit.
} 
undocumented status but also about their queerness. Indeed, "in order to be truly creative, the citizen must overcome the force of habit by provoking a genuine encounter that poses the problem of how to act" 40 . The "genuine encounter" produced in "Undocumented and Awkward" is the one between undocumented as a practice and awkwardness as a perspective. On one side, being undocumented is not presented as a status opposed to the status of citizenship in a rigid dichotomy: on the contrary, it is turned into a practice which give significance to an identity, but, also, overturns the lack of something - the documents, and, therefore, citizenship - into the creation of something else. This aspect is particular important in order to understand the time frame in which UndocuQueers in the series move: they struggle to be recognized as citizens and as queers, but the foundation of their identity is delivered to the future as "undocumented and queer". When the struggle will be won, allegedly, UndocuQueers will probably continue to identify as such. As Butler argues: "the changeable life of that term does not preclude the possibility of its use. If a term becomes questionable, does that mean it cannot be used any longer, and that we can only use terms that we already know how to master?"41. The tension from undocumented status to citizenship is not represented as a teleological movement which draws subjects from a state to another: it is conceived more as an endless process of discussion of what it means to be undocumented and what are the contradictions of being a citizen: "to self-identify as a non-status person is to engage in an act of citizenship ${ }^{\prime \prime 2}$ and the power of self-definition creates unexpected practices.

On the other side, the awkwardness of the situations portrayed arises from the awkwardness of the subjects that enact them: they are unexpectedly emerging from an invisible and forgotten political territory, where they "not only lack the full range of citizenship rights, but they are also denied the opportunity to express themselves as political beings" ${ }^{\prime 3}$. Some scholars have analysed the discourse on visibility created within the UndocuQueer movement as a powerful rhetorical tool that resembles the emergence of queer subjects at the beginning of the 70s. In this sense, visibility is an act of citizenship per se, in the case of undocumented immigrants and in the case of queer, as it is part of their emergence as subjects. Nevertheless, in the case of UndocuQueers starring the series, I argue that visibility is not limited to a demonstration or a collective action: their coming out as undocumented lives in the potentially eternal space of visibility given by the web, turning their presence into a constant reminder of

\footnotetext{
${ }^{40}$ WHITE, Can an act..., op. cit., p. 46.

${ }^{41}$ BUTLER, op. cit., p. 162.

${ }^{42}$ NYERS, op. cit., p. 163.

43 Ibidem, p. 162.
} 
their existence. Their (visible) bodies become the connection point between an everyday practice of citizenship and a public, broader dimension of discourses:

The body implies mortality, vulnerability, agency: the skin and the flesh expose us to the gaze of others, but also to touch, and to violence, and bodies put us at risk of becoming the agency and instrument of all these as well. Although we struggle for rights over our own bodies, the very bodies for which we struggle are not quite ever only our own. The body has its invariably public dimension ${ }^{44}$.

Subjects portrayed in the series enact acts of citizenship, then, through their survival in situations of discrimination and exclusion; but their being enacting this survival is itself an act of citizenship, as it is itself a practice of dealing with the paradoxes of visibility/invisibility, inclusion/exclusion.

In "Undocumented and Awkward" the struggle for rights is a matter of consciously weaving the multiple intersections within the network of friendship, intimate relationships, family, care and support, in order to create the necessary tools to give sense to an unjust status. Although the reference to the DREAM Act as a problematic but still useful legislative progress is constant, the actual practice of citizenship is built outside the legal discourse: indeed, "acts of citizenship do not need to be found in law or enacted in the name of the law $^{\prime 45}$. Undocumented and queer subjects are inhabitants of the margin described by bell hooks ${ }^{46}$ : their state of deportability, together with constant exposition to heteronormative power, produces strategies of resistance which place them both outside legal mobilizations and inside a political debate. They then become answerable to justice through practices that erupts from injustice but not always involve law. "Undocumented and Awkward" indeed represents the practices of rights in their complexity and conveys the idea that citizenship is an awkward paradox, if we look at it from a perspective that gives name to all the intersectioning identities embodied by subjects.

\section{Conclusions: undoing citizenship}

The series "Undocumented and Awkward" may be regarded as a paradigmatic representation of the claims and the practices of the UndocuQueer movement. Its communicative potential is not, of course, immune from critical aspects and problematic issues such as the unresolved contradiction between disruptive claims and institutional legalizations and the risk of assimilationism - or queer-liberalism. These contradictory issues, together with a critical discussion

\footnotetext{
${ }^{44}$ BUTLER, Judith, Precarious life: the powers of mourning and violence, p. 26.

${ }^{45}$ ISIN, op. cit.

${ }^{46}$ BELL HOOKS. Feminist theory from margin to center.
} 
of the political impact on the whole generation of young undocumented queer, need further analysis, as the UndocuQueer movement is still recent.

Nonetheless, the analyses of "Undocumented and Awkward" within the framework of acts of citizenship offers several insights which open the way for further debate. In first place, UndocuQueers - and the cultural contribution produced within it - are without any doubt a specific product of their space and time: the convergence of the DREAM Act discussion, the cultural resources of the young activist involved and a political debate on undocumented status born in the U.S.A. years ago are significant elements which created the basis for the emergence of the movement. There is a double fold consequence to that. On one side, UndocuQueer movement is an American movement, born in the U.S.A. under specific national circumstances; the UndocuQueers themselves use cultural and artistic references that are deeply embedded in the American context. Nonetheless, on the other side, the claims and the issues of the movement may be translated to other local contexts thanks to the cultural and artistic representation produced through examples like "Undocumented and Awkward". The narratives about, by and for undocumented youth are creative acts of citizenship which bring the local struggle to a broader scale of debate on citizenship, inclusion, visibility and rights: therefore, it is possible to imagine a cultural translation of this experience across scales which may give rise to local and transnational common struggles or forms of mobilization.

The groundbreaking potential of the UndocuQueer movement does not only reside in the creative and cultural representation of its struggles. It lies also in the practices enacted by its subjects: it is a process of engagement with boundaries and deprivation created by the confrontation with exclusion and citizenship. The persistent repetition of the prefix "un" in the visual campaigns of the movement and in the series presents a constant practice of undoing, where what is generally perceived as a lack is overturned and transformed into a plus: undocumented people, potentially afraid, ashamed, apologetic, become unafraid, unashamed, unapologetic. Through an opposition to deprivation, UndocuQueers actually react "reclaiming the discourse that defines their existence" ${ }^{\prime 47}$ : their narratives completely embrace the queer challenge of practicing failure ${ }^{48}$. Undocumented, just as queer, is transformed into a political practice, which is connected to an identity but, at the same time, overcomes rigid identity positioning in order to deal with complexity.

Also, Undocuqueers as activist citizens do have an important role within the DREAMers movement. After years of mobilizations, the American Senate has not fully passed the law and the struggle of undocumented people still

\footnotetext{
47 NYERS, op. cit., p. 170.

${ }^{48}$ HALBERSTAM, Judith. The queer art of failure.
} 
continues. Although the mobilization has in fact produced a great impact in the government and made it possible that some parts of the Act were accepted, there is still a lot to do. The Undocuqueer branch of the movement actually was effective in creating a cultural landscape of narratives addressed to all the other undocumented people: while talking to the undocumented movement as a whole, Undocuqueers addressed their narratives to all the others outside the movement. Cultural activism shaped a dialogue of narratives and representation between the movement and the civil society. For this reason, whatever further development of the movement will bring to the American political landscape, the UndocuQueer movement does represent a ground-breaking example of mobilization of rights: an example which leaves open discussion on how practices of citizenship may emerge outside the symbolic regime of law and arise from unexpected, uncanny, unafraid subjects.

\section{References}

ALEXANDER, Jonathan; RHODES, Jacqueline. Sexual rhetorics: methods, identities, publics. New York: Routledge, 2016.

ARENDT, Hannah. The Jew as Pariah. New York: Grove Press, 1982.

BELL HOOKS. Feminist theory from margin to center. Boston, MA: South End Press, 1984.

BIGGERS, Jeff. Undocumented and Awkward video series: Dreamers Adrift is the nation's most real reality TV show. 2016. Available at: <http://www. huffingtonpost.com/jeff-biggers/dreamers-adrift_b_1157743.html>. Accessed on 16.02.2016.

BUTLER, Judith. Excitable speech: a politics of the performative. New York: Routledge, 1997.

BUTLER, Judith. Precarious life: the powers of mourning and violence. London: Verso, 2004.

CHÁVEZ, Karma R. Queer migration politics activist rhetoric and coalitional possibilities. Urbana: University of Illinois Press, 2013.

DE GENOVA, Nicholas. Migrant 'Illegality' and deportability in everyday life. Annual Review of Anthropology, n. 31, 2002, p. 419-447.

DE GENOVA, Nicholas. The queer politics of migration: Reflections on 'illegality' and incorrigibility. Studies in Social Justice, v. 4, n. 2, 2010, p. 101-126.

DE GENOVA, Nicholas. 'We are of the connections': migration, methodological nationalism, and 'militant research'. Postcolonial Studies, v. 16, n. 3, 2013, p. 250-258.

DREAMERS ADRIFT. About us. 2011. Available at: <http://dreamersadrift.com/ about>. Accessed on 03.02.2016.

DREAMERS ADRIFT. Undocumented and Awkward: Episode 5. 2011. Available at: $<$ https://www.youtube.com/watch?v=-GgxF-cOLeQ> . Accessed on 02.02.2016. 
DREAMERS ADRIFT. Undocumented and Awkward: Episode 10. 2012. Available at: <https://www.youtube.com/watch?v=O7HQS14y8p4>. Accessed on 03.02.2016.

DREAMERS ADRIFT. Undocumented and Awkward 2.0: Episode 1. 2015. Available at: <https://www.youtube.com/watch?v=I5hvMBm5xGE >. Accessed on 03.02.2016.

FLORES, William. Citizens vs. Citizenry: Undocumented Immigrants and Latino Cultural Citizenship. In FLORES, William; BENMAYO, Rina (orgs.). Latino Cultural Citizenship: Claiming Identity, Space, and Rights. Boston: Beacon Press, 1997.

KING, Nia. Undocumented and awkward: an interview with Julio Salgado. 2013. Available at: <http://youngist.org/undocumented-and-awkward-an-interviewwith-julio-salgado/\#.VtOQQ8DJy2x>. Accessed on 15.02.2016.

KRAUSE, Monika. Undocumented Migrants An Arendtian Perspective. European Journal of Political Theory, v. 7, n. 3, 2008, p. 331-348.

HALBERSTAM, Judith. The queer art of failure. Durham: Duke University Press, 2011.

ISIN, Engin. Theorizing acts of citizenship. In ISIN, Engin; NIELSEN, Greg MarC (orgs.). Acts of citizenship. London: Zed Books Ltd, 2008.

ISIN, Engin; NIELSEN, Greg Marc. Acts of citizenship. London: Zed Books Ltd, 2008. MARCINIAK, Katarzyna. Legal/illegal: protesting citizenship in Fortress America. Citizenship Studies, v. 17, n. 2, 2013, p. 260-277.

NYERS, Peter. No one is illegal betweeen city and nation. In ISIN, Engin; NIELSEN, Greg Marc (orgs.). Acts of citizenship. London: Zed Books Ltd, 2008.

PAPADOPOULOS, Dimitris; TSIANOS, Vassilis. After citizenship: autonomy of migration, organisational ontology and mobile commons. Citizenship Studies, v. 17, n. 2, 2013, p. 178-196.

PASOLINI, Pier Paolo. Lettere luterane. Torino: Einaudi, 1976.

RIVAS, Jorge. What's it like to be young and undocumented? Awkward, says new video. 2011. Available at: <http://www.colorlines.com/articles/whatsit-be-young-and-undocumented-awkward-says-new-video $>$. Accessed on 16.02.2016.

RODRIGUEZ, Favianna. Meet the UndocuArtists: using art \& culture for immigrant justice, \& much more!. Available at: < http://culturalorganizing.org/meet-theundocuartists-using-art-culture-for-immigrant-justice-much-more/ $>$. Accessed on 15.02.2016.

SALGADO, Julio. I make art so that I don't feel like the only one going thru this shit. Going at it alone is tough. It's sad. We in it together. Tweet from: @julio1983. Accessed on 17.02.2016.

SEIF, Hinda. 'Coming out of the shadows' and 'UndocuQueer': undocumented immigrants transforming sexuality discourse and activism. Journal of Language and Sexuality, v. 3, 2013, p. 87-120. 
WHITE, Melanie. Can an act of citizenship be creative? In ISIN, Engin; NIELSEN, Greg Marc (orgs.). Acts of citizenship. London: Zed Books Ltd, 2008.

WHITE, Melissa Autumn. Documenting the undocumented: Toward a queer politics of no borders. Sexualities, v. 17, n. 8, 2014, p. 976-997.

Received for publication in June $30^{\text {th }}, 2016$

Accepted for publication in August 02 ${ }^{\text {nd }}, 2016$

Recebido para publicação em 30.06.2016

Aceito para publicação em 02.08.2016

ISSN impresso 1980-8585

ISSN eletrônico 2237-9843

http://dx.doi.org/10.1590/1980-85852503880004808 